\title{
Usability Testing for Crop and Farmer Activity Information System
}

\author{
Halim Budi Santoso ${ }^{1}$, Argo Wibowo ${ }^{4}$ \\ Department of Information System \\ Duta Wacana Christian University \\ Yogyakarta, Indonesia
}

\author{
Rosa Delima², Emylia Intan Listyaningsih ${ }^{3}$ \\ Department of Informatics \\ Duta Wacana Christian University \\ Yogyakarta, Indonesia
}

\begin{abstract}
Information System usability level depends on acceptance and system convenience to be run by users. One of the methods to measure usability level is by conducting usability testing. This article elaborates usability testing for Crop and Farmer Activity Information System. This system is one of the agriculture information systems that is developed to record system activities for each farm field. This system is considered as one of the important role of Information and Communication Technology (ICT) for agriculture. This system has been developing since 2017 and needs to be assessed and tested. To assess the system, usability testing was conducted by taking sampling from two regions in Central Java, Temanggung and Gombong. The respondents are system administrators, farmers, and general users with each of respondents has different criteria. There are 58 respondents participated in this research: 49 farmers, 3 system administrators, and 6 general users. Usability testing was carried out by giving respondents several test tasks based on the system. Each respondent had different kind of test task in accordance with the system functionality for each user. The result of the test found that system administrator user interface assessment value gained average percentage of $69 \%$, while the farmers gained $76 \%$ and general users gained $79 \%$. From the test, it also bring some recommendations for system refinement. Those recommendations were taken from user inputs and user test results. The recommendations have been made to bring better system environment.
\end{abstract}

Keywords-Usability testing; crop and activity information system; improvement recommendation; precision farming; information technology for agriculture

\section{INTRODUCTION}

Agriculture is one of the biggest sectors in Indonesia. Indonesia is popular with diversity of crop: rice, corn, sugar, and soybeans [1]. Historically, agriculture contributed to Indonesia's economic growth and decrease unemployment. It also helped government to decrease poverty rate [1]. Agriculture sector has low productivity while the number of people engaged in this sector is very high [2]. This problem becomes one of the challenges for the government. To increase the farmer's productivity, there are some important things should be handled [1]: 1) Government should focus on farmer incomes; 2) Government should increase the productivity through research and extension system; 3) Government is able to provide funding by giving farmer credit from state budget; 4) Government is able to help farmer by giving access to irrigation and building infrastructure for irrigation; 5)
Government should protect agriculture sector and farmer from imported diseases and increase agriculture product standards.

Information and Communication Technology (ICT) is one of tools that can help government to increase farmer's productivity. Initiatives to develop rural information and communication technology (ICT) bring an opportunity to disseminate information to rural communities. Evolution of smartphone user also helps ICT penetration to rural area. Implementation of ICT for agriculture encourages an innovation in ICT for agriculture. Implementation of ICT in agriculture is able to help in three main processes [3]: (1) Land selection and calendar definition by giving information systems including Decision Support System, Management Information System, or Geographic Information System; (2) ICT enabled learning and knowledge exchange by helping in calendar definition, land preparation, access in credit for farmer, water management, and input management; (3) Networking and eCommerce to help agriculture product marketing.

One of the systems that is enabled ICT role for agriculture is by providing information system for crop and farmer activity. Researchers has been developing crop and farmer activity in order to collect and issue crop data collection, planting calendar definition, farmer activity, and agriculture product data collection [4]. Crop and Farmer activity Information System is also able to provide report graphically and summarize data. The system is also able to predict harvest time for farmers in some specific calendar [4].

Crop and Farmer Activity Information System has been developing since 2017. This system needs to be evaluated and tested to measure system satisfaction level and give improvement recommendation. Therefore, usability testing and evaluation should be conducted to achieve system efficiency, effectiveness, and satisfaction. The objective of this research is to evaluate system interface using usability testing. From the evaluation, some improvement recommendation is conducted to bring better user interface and the system is able to be used easily.

This paper is discussed the study background and what has been done in the previous research. Following the first part, researchers discuss about usability testing and some researches were conducted related with usability testing. Research methodology is the next part and followed by discussion and analysis. The last part is the conclusion and recommendation for future works. 


\section{LITERATURE REVIEW}

\section{A. Crop and Farmer Activity Information System}

Crop and Farmer Activity Information System is a system that gives information to the user related to crop specification, planting calendar, and prediction of harvest time [4]. This system is developed in Indonesia Language since the system is targeted to users (farmer, farmer group representative, and academician). Crop data collection provides detail information about crop and specific characteristics. Figure 1 shows crop information page.

Figure 1 shows Crop Information Page which provides detail information about the crop. Some detail information like root characteristic, trunk characteristic, leave characteristic, fruit and seed characteristic. This information is available for farmer, farmer group representative, and academician [4]

Detail Tanaman Bawang Merah

< Kembali ke Daftar Tanaman
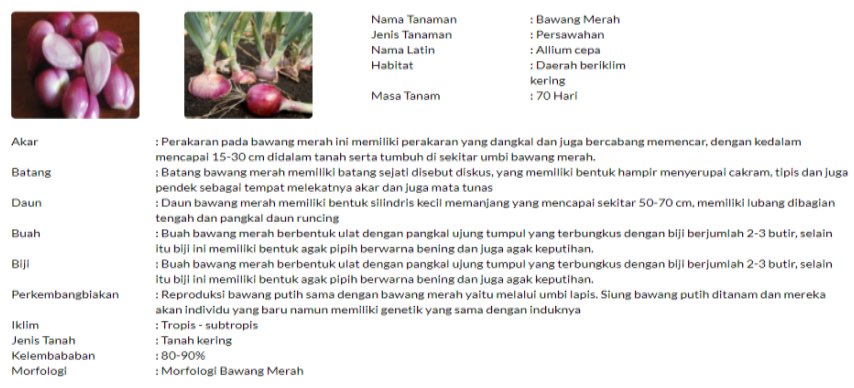

Fig. 1. Crop Information Page [4].

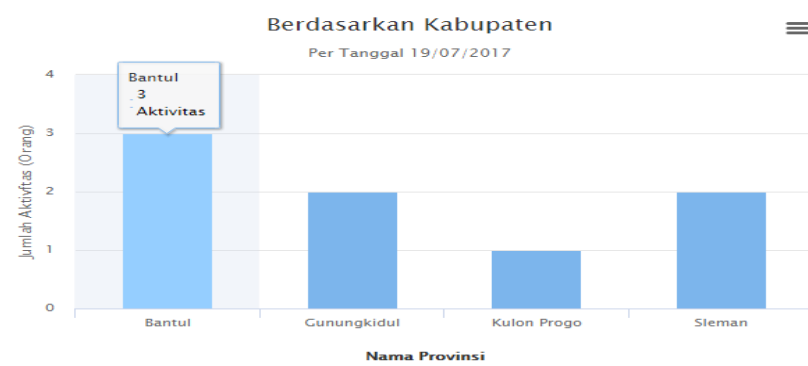

Fig. 2. Number of Land Preparation Activity in Yogyakarta Special Region [4].

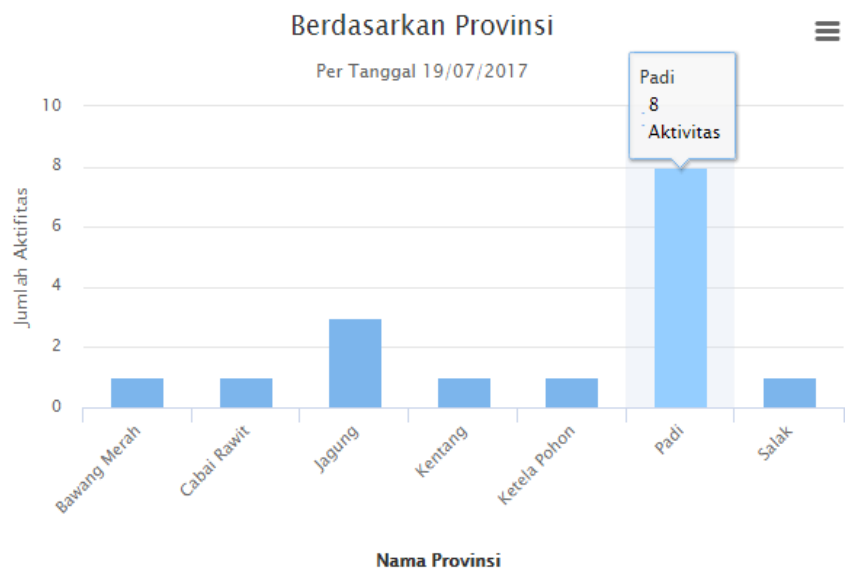

Fig. 3. Farmer Planting Activity Based on Crop and Region [4].
Another function available in this system is farmer activity. This feature provides a system for farmer to entry specified information related with what activity they do. This data bring information about the number of farmer activities (figure 2, figure 3) and yields (figure 4, figure 5) based on district and crop.

Figure 2 and 3 shows the farmer activity reports and summary. This report provides information about the number of farmers or users which conducting specific activity (figure 2). On the other hand, figure 3 shows information about the number of crop planted by farmers. This two reports can be drilled down based on region or province.

Fig 4 and 5 brings information of the amount of yield for specified date. This information are generated from the data entered by farmers. These four graphics are able to cascade down to get more detail information.

\begin{tabular}{lll} 
No & Nama Tanaman & Jumlah Panen (Kuintal) \\
\hline 1 & Padi & 140 \\
\hline 2 & Bawang Merah & 15 \\
\hline 3 & Bawang Putih & \\
\hline 4 & anggrek & 30 \\
\hline 5 & Jagung & \\
\hline 6 & Gandum & \\
\hline 7 & Bayam & \\
\hline 8 & Kentang & 20 \\
\hline 9 & Kedelai & 50 \\
\hline 10 & Ketela Pohon & 10 \\
\hline 11 & Salak & 265 \\
\hline 12 & Cabai Rawit & Total \\
\hline
\end{tabular}

Fig. 4. Information related the Number of Yields (in quintal) [4].

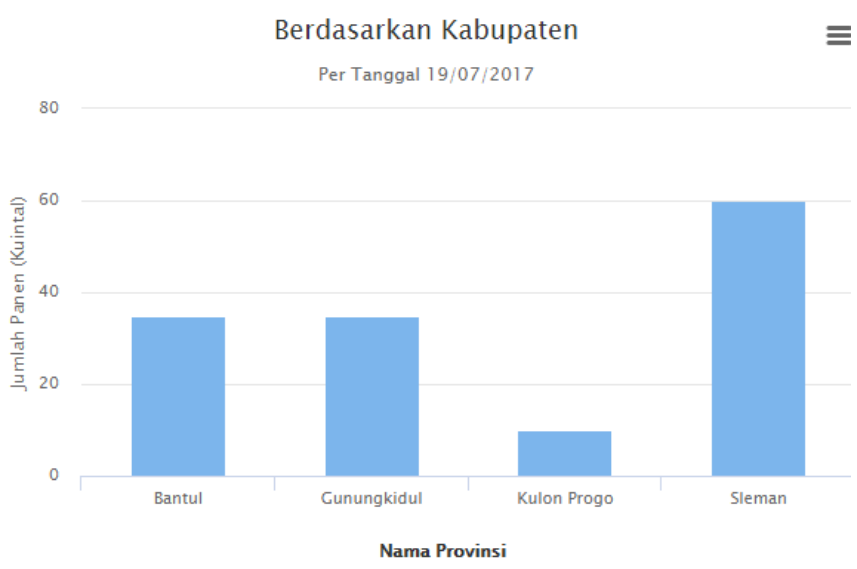

Fig. 5. Yield Information based on Region [4]. 


\section{B. Usability Evaluation and Testing}

Usability has been defined as a measurement of system effectiveness, efficiency, and satisfaction [5]. Usability is also an assessment to measure quality level and human point of view about the systems [6] [7]. Mack and Nielsen [8] categorized the evaluation method into four classification: (1) Usability evaluation through evaluation software; (2) Usability testing is assessed by evaluating the user interface with real user; (3) Usability measures by using models and formulas; (4) Usability is measured based on rules of thumb and the general skill, knowledge, and experience of the evaluators. The usability testing is an assessment method to measure the degree of interactive system is easy and pleasant to use with a view of identifying usability problems and / or a collection of usability measures / metrics [9]. Thus, usability is a media to gain good quality of web, by measuring reliability, functionality, usability, efficiency, maintainability, and portability [7].

Usability has 5 quality components [10]: (1) Learnability: How easy the users to finish task given and how fast user understand functionalities in the system; (2) Efficiency: How fast the user can perform the tasks given after learn the system; (3) Memorability: How easily user can reestablish proficiency after a period of time do not use it; (4) Errors: How many times users do error and how easily the users can recover from the errors? (5) Satisfaction: How positive the users against the system user interface. Usability is necessary for system survival. People will choose the system that is easily to be used. People will not use the system that difficult to be used [10]. Thus, usability testing is done to test those 5 quality components.

Usability is concerned with quantitative and qualitative analysis, which is measured timed-based and traffic-based data [9]. Usability level is gained by conducting testing for respondents by distributing the questionnaire. Each question will be tested validity and readability that the data obtained from the questionnaire can be used as a solid basis for research data [11].

Usability testing has been conducting for some research topics. Lestari [12] conducted usability testing to test web application for small and medium enterprise in Bandung, West Java, Indonesia. Usability is measured using Post-study System Usability Questionnaire (PSSUQ). There are four reviews: overall satisfaction score (OVERALL), system usability (SYSUSE), information quality (INFOQUAL), and user interface quality (INTERQUAL). From the study, it is found that $56 \%$ of the respondents are satisfied with the system $(4.22$ for OVERALL points). $64 \%$ of respondents agree that web application helps them to promote their products (4.43 for SYSUSE points). Small and medium enterprise site does not have complete information for product catalogue. It makes information quality score only 3.71 with $36 \%$ respondents agree. On the other hand, $60 \%$ respondents agree that the system has good quality user interface.

Usability testing was also done to evaluate government websites [13]. This paper is to study whether the government websites fulfills the Nielsen usability components. To find the result, 30 users were given some tasks and post-test questionnaires. Those tasks are related with finding some information in the e-Government sites and post-test questionnaires included Nielsen's usability components. From the tasks and post-test questionnaires, it is found that most of users (27 respondents) agreed that the e-Government websites is quick to perform. 28 of 30 respondents also agree that the eGovernment sites are easily to be remembered and they are satisfied with the websites. With the new user interface, eGovernment sites quicker to perform, easier to understand, and more satisfied. The researchers already conducted the third test and it is found that the result from the third test increased comparing with the other two tests.

Usability evaluation was also done to test the e-Learning system in one of the public universities in Kenya [14]. This university has implemented Moodle e-Learning system. This research is to find what factors that are affected the usability of e-Learning system. The components that were tested in this evaluation: learnability, user-friendliness, technological infrastructure, usability policy, culture, and gender. From the study, it is found that the learnability brings significant affect to usability of e-Learning system. It is suggested that to enhance e-Learning system in the university, the system should be easily to be learnt. User friendly factor also affects the user ability. E-Learning should be user friendly to be usable in the university [14].

Usability testing is also to test one of the biggest community site in Indonesia, kaskus.co.id. There are some problems found in this research, such as the process of the posting, the advertisement on the page which makes user inconvenience, and difficulties to organize picture in this community [15]. Some influential factors of website, such as simplicity, user-friendliness, comfort, navigability, link visibility, high and readable color contrast, and right to the point information got medium point, which range from 0.2 to 0.6. The finding is also got moderate level of usability for kaskus, the community site in Indonesia [15]

\section{ReSEARCh MethodOlOGY}

Starting this research, researchers did literature study and exploring crop and farming activity system. This initial study was conducted to observe research methodology and explore system functionalities. After finishing initial study, researchers define the respondents. There are 58 respondents from two regions in central java, Gombong and Temanggung, involved in this research. Those respondents are categorized into 3 kinds of users with each user has specific ability and requirements: (1) Farmer: Farmer respondents should be able to operate computer and / or smartphone, minimum age is 20 , and graduate minimum from junior high schools; (2) System Administrator. System administrator should be able to operate computer and understand the basic computer operation, and graduated from bachelor degree; (3) General User. General user graduated at least from junior high school, minimum age is 20 , has the ability to operate computer and / or smartphone. General user can be government as a representative from department of agriculture, academician, or civil society.

After defining the respondents, the next step in this research is defining tasks with these following criteria: (1) Task description should be available in each task; (2) The tested page should appear when user do the task on the tested 
page; (3) There should be explanation about the task step in each task given; (4) Success task is given when respondent is able to finish the task; (5) Maximum time (second) is time limitation for respondents to finish each task. Table 1 below describes task for farmers:

Table I, II, and III shows the detail tasks for specific users. To test this website usability, there are some indicators: (1) Task Success. This indicator measures user effectiveness in order to finish the task; (2) Time on task. This indicator measures how much time respondent needs to finish a task; (3) Error. This indicator evaluates respondent performance to use the system; (4) Efficiency. This indicator measures the system efficiency to finish the tasks by count the number of click.

Researchers also prepared test scenario for respondents, as follows: (1) Usability testing is carried out one by one respondent of each required criteria; (2) Respondent will be provided with a laptop with the system displayed on the laptop; (3) Usability testing is conducted at the flexible places; (4) Researchers explain each step of testing step; (5) Respondent will be given a document about system description and task; (6) Researchers record processing time for a respondent to finish a task, count errors that happen during doing the test; count the number of click to finish a task.

Researchers will analyze the data with metric usability task success, metric usability - time on task, error data analysis, and efficiency data analysis. The next step after analyzing the data is making some improvement recommendation. Improvement recommendation is given based on the usability test result.

TABLE I. TESTED TASKS FOR FARMER RESPONDENT

\begin{tabular}{|c|c|c|c|c|c|}
\hline No & Description & Things to Do & Success Criteria & $\begin{array}{l}\text { Maximum } \\
\text { Time (in } \\
\text { second) }\end{array}$ & $\begin{array}{l}\text { Minimum } \\
\text { Clicks }\end{array}$ \\
\hline 1 & $\begin{array}{l}\text { Login to Crop and Farmer Activity } \\
\text { Information System } \\
\text { Username: us } 2 \\
\text { Password : } 123\end{array}$ & $\begin{array}{l}\text { a. Search and find link to login to } \\
\text { the system } \\
\text { b. Entry some textboxes to login } \\
\text { page }\end{array}$ & $\begin{array}{l}\text { Respondent is able to login to } \\
\text { the system. The system will } \\
\text { give output WELCOME ..... } \\
\text { on the main menu }\end{array}$ & 31.32 & 4 \\
\hline 3 & $\begin{array}{l}\text { Change the description of a crop. Use } \\
\text { garlic for an example }\end{array}$ & $\begin{array}{l}\text { Search EDIT button and update } \\
\text { data }\end{array}$ & $\begin{array}{l}\text { After success to change the } \\
\text { description, system will show } \\
\text { pop up message "Data is } \\
\text { successful to be updated". }\end{array}$ & 91.24 & 4 \\
\hline 4 & $\begin{array}{l}\text { Add a data in menu crop. } \\
\text { Spesies : Corn } \\
\text { Harvest Year : } 2018 \\
\text { Harvest period : } 4 \\
\text { Land area : } 30 \mathrm{~m} 2 \\
\text { Total weight : } 20 \text { kuintal } \\
\text { Product : corn seed }\end{array}$ & $\begin{array}{l}\text { a. Search link Add Data } \\
\text { b. Entry some fields in the menu } \\
\text { add data } \\
\text { c. Save the new data which is } \\
\text { entered in the previous step }\end{array}$ & $\begin{array}{l}\text { After succeceed to find link } \\
\text { Add Data, respondent should } \\
\text { entry some data in the } \\
\text { textboxes and save it. There } \\
\text { will be a pop up messages }\end{array}$ & 219.6 & 13 \\
\hline 5 & $\begin{array}{l}\text { See detail information of onion plant } \\
\text { data. }\end{array}$ & Find and click link Show & $\begin{array}{l}\text { System will show detail } \\
\text { information of onion plant } \\
\text { data }\end{array}$ & 98.76 & 5 \\
\hline 6 & See the family of plant morphology & $\begin{array}{l}\text { a. Find plant morphology } \\
\text { b. Find the family data of specific } \\
\text { data }\end{array}$ & $\begin{array}{l}\text { System will show family of } \\
\text { given plant data }\end{array}$ & 74.6 & 3 \\
\hline 7 & Print all data of planting calendar & $\begin{array}{l}\text { a. Find link to print data and } \\
\text { download the data } \\
\text { b. Search data in the download } \\
\text { folder and show the data }\end{array}$ & $\begin{array}{l}\text { System will show the } \\
\text { downloaded data }\end{array}$ & 56.2 & 5 \\
\hline 11 & $\begin{array}{l}\text { Print to excel format the harvest graph } \\
\text { which is got from task } 10 .\end{array}$ & $\begin{array}{l}\text { a. Find the link "Print" } \\
\text { b. Show the data on the excel } \\
\text { format }\end{array}$ & $\begin{array}{l}\text { System will show the graph, } \\
\text { download the data, and show } \\
\text { on the excel format }\end{array}$ & 21.24 & 3 \\
\hline
\end{tabular}


TABLE II. TESTED TASKS FOR SYSTEM ADMINISTRATOR RESPONDENT

\begin{tabular}{|c|c|c|c|c|c|}
\hline No & Description & Things to Do & Success Criteria & $\begin{array}{l}\text { Maximum } \\
\text { Time (in } \\
\text { second) }\end{array}$ & $\begin{array}{l}\text { Minimum } \\
\text { Clicks }\end{array}$ \\
\hline 1 & $\begin{array}{l}\text { Login to Crop and Farmer Activity } \\
\text { Information System } \\
\text { Username : us1 } \\
\text { Password : } 123\end{array}$ & $\begin{array}{l}\text { a. Find and click Login link } \\
\text { b. Fill some textboxes from login } \\
\text { page }\end{array}$ & $\begin{array}{l}\text { Respondent is able to login to } \\
\text { the system and system shows } \\
\text { WELCOME message }\end{array}$ & 13.7 & 4 \\
\hline 2 & $\begin{array}{l}\text { Add corn detail morphology } \\
\text { ID : Corn } \\
\text { Name : Corn Morphology } \\
\text { Division : Angiosperm } \\
\text { Subdivision : Zea } \\
\text { Ordo : Poales } \\
\text { Familiae : Poaceae }\end{array}$ & $\begin{array}{l}\text { a. Find and click Link : Add Data } \\
\text { from the system } \\
\text { b. Fill some textboxes with the } \\
\text { data } \\
\text { c. Save the new data }\end{array}$ & $\begin{array}{l}\text { Respondent will get messages } \\
\text { Data is succeed to be entered } \\
\text { and system will show the data }\end{array}$ & 82.9 & 10 \\
\hline 3 & Edit data of Corn Morphology & $\begin{array}{l}\text { a. Find and click link Edit } \\
\text { b. Update some spesific data of } \\
\text { morphology lists } \\
\text { c. Save the changes }\end{array}$ & $\begin{array}{l}\text { System will show the pop up } \\
\text { messages to indicate that the } \\
\text { data is successfully to be } \\
\text { updated. }\end{array}$ & 49.8 & 5 \\
\hline 4 & $\begin{array}{l}\text { Print the plant data and show the } \\
\text { downloaded data }\end{array}$ & $\begin{array}{l}\text { a. Find and click Print link } \\
\text { b. Find the downloaded data }\end{array}$ & System will show the data & 29.1 & 6 \\
\hline 5 & $\begin{array}{l}\text { Find and see the corn planting } \\
\text { calendar in Bantul region }\end{array}$ & Search and click link SHOW & $\begin{array}{l}\text { System will show the } \\
\text { complete corn planting } \\
\text { calendar data }\end{array}$ & 31.6 & 4 \\
\hline 6 & $\begin{array}{l}\text { Print the data of land map and show } \\
\text { the data }\end{array}$ & $\begin{array}{l}\text { a. Search and click link PRINT } \\
\text { b. Search and print data }\end{array}$ & $\begin{array}{l}\text { System will download data on } \\
\text { the excel format }\end{array}$ & 21.15 & 5 \\
\hline 7 & $\begin{array}{l}\text { On the farmer activity menu, find the } \\
\text { data persiapan1. Delete that data. }\end{array}$ & Search and click link DELETE & $\begin{array}{l}\text { System will delete the data } \\
\text { permanently }\end{array}$ & 34.65 & 5 \\
\hline 8 & $\begin{array}{l}\text { On the farmer activity menu, find the } \\
\text { land preparation data }: 12 \text { and update } \\
\text { the period become period }: 8\end{array}$ & $\begin{array}{l}\text { a. Find the search bar } \\
\text { b. Click update } \\
\text { c. Do some changes in data } \\
\text { d. Submit }\end{array}$ & $\begin{array}{l}\text { System will show the pop up } \\
\text { messages "Data is successed } \\
\text { to be updated" }\end{array}$ & 44.5 & 7 \\
\hline
\end{tabular}

TABLE III. TESTED TASKS FOR GENERAL USER RESPONDENT

\begin{tabular}{|c|c|c|c|c|c|}
\hline No & Description & Things to Do & Success Criteria & $\begin{array}{l}\text { Maximum } \\
\text { Time (in } \\
\text { second) }\end{array}$ & $\begin{array}{l}\text { Minimum } \\
\text { Clicks }\end{array}$ \\
\hline 1 & See detail information of onion plant & $\begin{array}{l}\text { a. Search plant menu } \\
\text { b. Search onion plant data } \\
\text { c. Press button "Show" }\end{array}$ & $\begin{array}{l}\text { System will show the detail } \\
\text { information of onion plant }\end{array}$ & 23.8 & 4 \\
\hline 2 & Print all plant morphology data & $\begin{array}{l}\text { a. Search plant morphology } \\
\text { menu } \\
\text { b. Search and press button } \\
\text { "Print" }\end{array}$ & $\begin{array}{l}\text { System will download data } \\
\text { into xls format }\end{array}$ & 22.64 & 3 \\
\hline 3 & $\begin{array}{l}\text { Show the printed data which has been } \\
\text { done in task } 2\end{array}$ & $\begin{array}{l}\text { a. Search the downloaded data } \\
\text { b. Show the downloaded data }\end{array}$ & $\begin{array}{l}\text { The data will be opened in } \\
\text { spreadsheet application }\end{array}$ & 26.04 & 2 \\
\hline 4 & $\begin{array}{l}\text { Find the detail information of Corn on } \\
\text { the planting calendar menu }\end{array}$ & $\begin{array}{l}\text { a. Find the planting calendar } \\
\text { menu } \\
\text { b. Find button "Show" }\end{array}$ & $\begin{array}{l}\text { System will show corn detail } \\
\text { data and information }\end{array}$ & 19.52 & 4 \\
\hline 5 & $\begin{array}{l}\text { Find end month of corn season with } \\
\text { latitude and longitude coordinat in the } \\
\text { land map menu }\end{array}$ & $\begin{array}{l}\text { a. Search land mapping menu } \\
\text { b. Search corn data } \\
\text { c. Find button " +" to see end } \\
\text { month of corn season }\end{array}$ & $\begin{array}{l}\text { System will show end month } \\
\text { of corn season data with } \\
\text { longitude and latitude } \\
\text { coordinate }\end{array}$ & 18.2 & 3 \\
\hline
\end{tabular}




\begin{tabular}{|c|c|c|c|c|c|}
\hline No & Description & Things to Do & Success Criteria & $\begin{array}{l}\text { Maximum } \\
\text { Time (in } \\
\text { second) }\end{array}$ & $\begin{array}{l}\text { Minimum } \\
\text { Clicks }\end{array}$ \\
\hline 6 & $\begin{array}{l}\text { Look at the graphic detail of } \\
\text { plantation data. }\end{array}$ & $\begin{array}{l}\text { a. Search graphic plant menu } \\
\text { b. Choose and click plantation } \\
\text { graphic }\end{array}$ & $\begin{array}{l}\text { System will open the plant } \\
\text { data and show the graphic }\end{array}$ & 31.76 & 3 \\
\hline 7 & Look at the potato detail information & $\begin{array}{l}\text { a. Search potato data } \\
\text { b. Search and click button } \\
\text { "Show" }\end{array}$ & System will open potato data & 20.96 & 1 \\
\hline 8 & $\begin{array}{l}\text { Download the type of soil graphic on } \\
\text { the PNG format }\end{array}$ & $\begin{array}{l}\text { a. Search the type of soil data } \\
\text { b. Download and Open the } \\
\text { graphic }\end{array}$ & $\begin{array}{l}\text { System will download the } \\
\text { graphic and open it }\end{array}$ & 29.64 & 4 \\
\hline 9 & Open the PNG graphic & $\begin{array}{l}\text { Search and open the downloaded } \\
\text { data }\end{array}$ & Monitor will show the graphic & 9.24 & 1 \\
\hline 10 & $\begin{array}{l}\text { Search the cassava data on the farmer } \\
\text { activity }\end{array}$ & $\begin{array}{l}\text { a. Find the search bar } \\
\text { b. Fill the search bar } \\
\text { c. Click and press button } \\
\text { "Search" }\end{array}$ & $\begin{array}{l}\text { System will show the data that } \\
\text { contains word: cassava }\end{array}$ & 47.12 & 4 \\
\hline 11 & $\begin{array}{l}\text { Search summary data from regional } \\
\text { activity graphic. } \\
\text { Year : } 2016 \\
\text { Plant : Onion } \\
\text { Activity : Land Preparation }\end{array}$ & $\begin{array}{l}\text { a. Search regional activity } \\
\text { graphic } \\
\text { b. Fill the textbox } \\
\text { c. Click and press button } \\
\text { "Submit" } \\
\text { d. Find and search button } \\
\text { "Summary" }\end{array}$ & $\begin{array}{l}\text { System will show summary } \\
\text { garlic data }\end{array}$ & 60.48 & 7 \\
\hline 12 & $\begin{array}{l}\text { Find the number of activities on plant } \\
\text { activity graphic with the following } \\
\text { data : } \\
\text { Province : Special Region of } \\
\text { Yogyakarta } \\
\text { Year : } 2015 \\
\text { Activity : Land Preparation }\end{array}$ & $\begin{array}{l}\text { a. Find and search plant activity } \\
\text { graphic } \\
\text { b. Fill some textboxes } \\
\text { c. Click "Submit" button } \\
\text { d. Direct mouse to the graphic }\end{array}$ & $\begin{array}{l}\text { System will show the number } \\
\text { of land preparation activity }\end{array}$ & 66.32 & 8 \\
\hline 13 & $\begin{array}{l}\text { Filter the harvest crop based on name. } \\
\text { Name : rice }\end{array}$ & $\begin{array}{l}\text { a. Find the harvest crop menu } \\
\text { b. Fill some textbox filter } \\
\text { c. Find and press filter button }\end{array}$ & $\begin{array}{l}\text { System will show the data that } \\
\text { contains word rice }\end{array}$ & 100.4 & 6 \\
\hline 14 & $\begin{array}{l}\text { See and show the ammount of rice } \\
\text { harvest graphic in Yogyakarta Special } \\
\text { Region }\end{array}$ & $\begin{array}{l}\text { a. Find the menu } \\
\text { b. Fill the textbox } \\
\text { c. Press submit button } \\
\text { d. Direct the cursor to the new } \\
\text { data }\end{array}$ & & $44 . .84$ & 6 \\
\hline 15 & $\begin{array}{l}\text { See the ammount of rice harvest in } \\
\text { Yogyakarta Special Region from } \\
2012-2016\end{array}$ & $\begin{array}{l}\text { a. Find the menu of harvest data } \\
\text { b. Fill some textboxes } \\
\text { c. Press submit button }\end{array}$ & $\begin{array}{l}\text { System will show the } \\
\text { ammount of harvest graphic } \\
\text { based on data entered }\end{array}$ & 99.4 & 12 \\
\hline 16 & $\begin{array}{l}\text { See the rice plant data and the amount } \\
\text { of harvest crop in } 2017\end{array}$ & $\begin{array}{l}\text { a. Find the graphic menu on } \\
\text { detail information of harvest } \\
\text { b. Fill some data and click } \\
\text { submit button } \\
\text { c. Find and click Summary data }\end{array}$ & $\begin{array}{l}\text { System will show summary } \\
\text { and the number of rice plant } \\
\text { harvest in Special Region of } \\
\text { Yogyakarta on } 2017\end{array}$ & 48.4 & 1 \\
\hline
\end{tabular}

\section{ANALYSIS AND DISCUSSION}

\section{A. Descriptive Statistics}

There are 58 respondents participated in this research: 49 farmers, 3 system administrators, and 6 general users. Based on age, those respondents can be categorized as follows:

Table IV shows the number of respondent based on age category. Almost $50 \%$ of respondent's age is 20 to 30 years old. There are 9 respondents are 41 to 50 years old as a farmer. There are also 3 general user respondents which are aged more than 51 years old.
TABLE IV. RESPONDENT PROFILE BASED ON AgE

\begin{tabular}{|l|l|l|}
\hline No & Age & Number of Respondent \\
\hline 1 & $<19$ years old & 0 \\
\hline 2 & $20-30$ years old & 24 \\
\hline 3 & $31-40$ years old & 22 \\
\hline 4 & $41-50$ years old & 9 \\
\hline 5 & $>51$ years old & 3 \\
\hline
\end{tabular}


TABLE V. RESPONDENT PROFILE BASED ON EDUCATION BACKGROUND

\begin{tabular}{|l|l|l|}
\hline No & Education & Number of Respondent \\
\hline 1 & Junior High School & 30 \\
\hline 2 & Senior High School & 25 \\
\hline 3 & Undergraduate Degree & 2 \\
\hline 4 & Graduate Degree & 1 \\
\hline
\end{tabular}

Table $\mathrm{V}$ shows the number of respondent based on education background. There are 30 respondents which are junior high school graduates. Those are farmer respondents. There are also 19 farmer respondents who graduate from senior high school. System administrator respondents graduate from senior high school. The rest are general user respondents and system administrator. There is a general user respondent who already completed master degree.

\section{B. Testing Result}

This research involved 58 respondents to finish several tasks to measure task success, time on task, error, and efficiency (number of click). Time on task is a measurement for user effectiveness to finish a task. While task success is a measurement of how many respondents are able to finish the task. Error is to calculate how many mistakes respondents did. And the last is efficiency as a measurement of how many efforts respondents did in a system. In this research, effectiveness is measured by counting the number of click respondent did during finishing a task.

\section{1) System administrator respondents}

The first step to conduct usability testing is measuring maximum time to do the tasks. Maximum time is got by taking 4 random samples and double average times to finish tasks.
Table VI shows the maximum time limit to do tasks. Each task has different maximum time. If the respondents are not able to finish task until the maximum time, respondents will be considered and assumed as an error. After completing the task, there are 3 respondents who are not able to finish task 4 on time, 2 respondents who are not able to finish task 5 on time, and 1 respondents who are not able to finish task 6 on time.

Table VII shows the success rate of system administrator task. Those task is filled with 1 if the respondent is succeed to finish the task and 0 if the respondent is failed to finisih the task. It is seen that there is no respondent who is able to finish the task 4 and only 1 respondent who is able to finish task 6 . Respondents are not able to finish task 4 since there is no symbol on the page menu or active label if the page is active. Thus, respondents faced difficulties while doing the task.

Contrary to the success rate calculation, error rate is to measure the respondents' error while finishing tasks. On task 4, respondents were not able to show crop menu. Respondents show crop / plant morphology data. Respondents are also not able to show the data which is given from the task.

The last measurement is efficiency (number of click). Efficiency is to measure how much efforts respondents do in a system. The number of click is compared with minimum click to finish task. The minimum click to finish the task is 46 . Table VIII below shows efficiency of system administrator by counting number of click.

Table VIII shows the system administrator efficiency. The number of click is slightly above the minimum number of click. The respondents explore the system functionality well. It makes respondents are able to click the tasks efficiently.

TABLE VI. BENCHMARK MAXIMUM TIME FOR SYSTEM ADMINISTRATOR

\begin{tabular}{|l|l|l|l|l|l|l|}
\hline Task & User 1 & User 2 & User 3 & User 4 & Avg & Max Time (Avg * 2) \\
\hline 1 & 7.3 & 8 & 5.3 & 6.8 & 6.85 & 13.7 \\
\hline 2 & 33.8 & 49.3 & 38.9 & 43.8 & 41.45 & 82.9 \\
\hline 3 & 18.8 & 25.5 & 22.5 & 32.8 & 24.9 & 49.8 \\
\hline 4 & 10.7 & 17.8 & 13.4 & 16.3 & 14.55 & 29.1 \\
\hline 5 & 16.6 & 11.3 & 17 & 18.3 & 15.8 & 31.6 \\
\hline 6 & 12.6 & 9.1 & 10.3 & 10.3 & 10.575 & 21.15 \\
\hline 7 & 14.2 & 13.9 & 22.7 & 18.5 & 17.325 & 34.65 \\
\hline 8 & 21.9 & 18.1 & 23.5 & 25.6 & 22.275 & 44.5 \\
\hline
\end{tabular}

TABLE VII. SYSTEM ADMINISTRATOR TASK SUCCESS

\begin{tabular}{|l|l|l|l|l|l|l|l|l|l|}
\hline User & Task 1 & Task 2 & Task 3 & Task 4 & Task 5 & Task 6 & Task 7 & Task 8 & Success \\
\hline 1 & 1 & 1 & 1 & 0 & 1 & 0 & 1 & 1 \\
\hline 2 & 1 & 1 & 1 & 0 & 1 & 0 & 1 & $75 \%$ \\
\hline 3 & 1 & 1 & 1 & 0 & 1 & 1 & 1 & 1 \\
\hline Succes & $100 \%$ & $100 \%$ & $100 \%$ & $0 \%$ & $100 \%$ & $33 \%$ & $100 \%$ & $100 \%$ & $79 \%$ \\
\hline
\end{tabular}

TABLE VIII. SYSTEM ADMINISTRATOR EFFICIENCY

\begin{tabular}{|l|l|l|l|l|l|l|l|l|l|}
\hline User & Task 1 & Task 2 & Task 3 & Task 4 & Task 5 & Task 6 & Task 7 & Task 8 & Sum \\
\hline 1 & 4 & 12 & 9 & 6 & 7 & 4 & 6 & 9 \\
\hline 2 & 4 & 12 & 5 & 4 & 5 & 4 & 8 & 6 \\
\hline 3 & 4 & 10 & 5 & 4 & 5 & 8 & 5 & 48 \\
\hline
\end{tabular}


TABLE IX. BENCHMARK MAXIMUM TIME FOR FARMERS

\begin{tabular}{|l|l|l|l|l|l|l|l|}
\hline Task & User 1 & User 2 & User 3 & User 4 & User 5 & Avg & Max Time (Avg * 2) \\
\hline 1 & 14.7 & 15.6 & 11.3 & 14.8 & 21.9 & 15.66 & 31.32 \\
\hline 2 & 15.9 & 43.9 & 17.3 & 69.6 & 96.1 & 48.56 & 97.12 \\
\hline 3 & 21.2 & 67.8 & 30.4 & 39.8 & 68.9 & 45.62 & 91.24 \\
\hline 4 & 59 & 124.5 & 68.5 & 132.3 & 164.7 & 109.8 & 219.6 \\
\hline 5 & 24.9 & 61.3 & 30.8 & 40.8 & 89.1 & 49.38 & 98.76 \\
\hline 6 & 16.9 & 30.4 & 29.9 & 43.8 & 65.5 & 37.3 & 74.6 \\
\hline 7 & 18.8 & 27.7 & 15.6 & 34.6 & 43.8 & 28.1 & 56.2 \\
\hline 8 & 59.4 & 10.9 & 22.4 & 65.8 & 74.7 & 46.64 & 93.28 \\
\hline 9 & 12.4 & 12.8 & 10.6 & 23.4 & 32.7 & 18.38 & 36.76 \\
\hline 10 & 3.9 & 7.3 & 5.5 & 8.4 & 11.8 & 7.38 & 14.76 \\
\hline 11 & 9.6 & 7.1 & 6.5 & 12.5 & 17.4 & 10.62 & 21.24 \\
\hline
\end{tabular}

2) Farmer respondents

There are 49 farmer respondents are involved in this research. Among those 49 respondents, there are 13 data is invalid because the respondents got help from the others to finish the task. Those invalid data are not analyzed. 5 respondents are chosen to benchmark maksimum time.

Table IX shows the maximum time limit to do several tasks. Based on those benchmark, it is shown the number of successful respondents based on time limitation.

Table X shows the successful respondents to finish the task based on the time limitations. Some tasks has good success rate. On the contrary, less than $50 \%$ respondents is not able to finish task 2, 5, 6, and 8. From the task 6 test, respondents are difficult to find edit button. Some of respondents think that ' + ' button is edit button. On task 9,10 , and 11 respondents should scroll down the page to find the summary button. From this task test, it is suggested to refine the system user interface to ease user to access the menu.

TABLE X. Number of RESPONDENTS Which NEEDS Time ABove AND Below MAXIMUM TIME LIMIT AND AVERAGE TIME TO FINISIH TASK

\begin{tabular}{|l|l|l|l|}
\hline $\begin{array}{l}\text { Ta } \\
\text { sk }\end{array}$ & $\begin{array}{l}\text { Number of Respondents } \\
\text { Below Max Time }\end{array}$ & $\begin{array}{l}\text { Number of Respondents } \\
\text { Above Max Time }\end{array}$ & $\begin{array}{l}\text { Average } \\
\text { Time } \\
\text { Used }\end{array}$ \\
\hline 1 & 30 & 6 & 6.197 \\
\hline 2 & 11 & 25 & 43.519 \\
\hline 3 & 21 & 15 & 28.533 \\
\hline 4 & 12 & 24 & 97.025 \\
\hline 5 & 6 & 30 & 48.427 \\
\hline 6 & 17 & 19 & 19.036 \\
\hline 7 & 18 & 18 & 21.261 \\
\hline 8 & 9 & 27 & 28.172 \\
\hline 9 & 26 & 10 & 7.458 \\
\hline 10 & 32 & 4 & 1.411 \\
\hline 11 & 32 & 4 & 2.25 \\
\hline
\end{tabular}

TABLE XI. SUCCESSFUl RATE OF EACH TASK

\begin{tabular}{|l|l|}
\hline Task & Success Rate \\
\hline 1 & $100 \%$ \\
\hline 2 & $89 \%$ \\
\hline 3 & $94 \%$ \\
\hline 4 & $92 \%$ \\
\hline 5 & $94 \%$ \\
\hline 6 & $94 \%$ \\
\hline 7 & $75 \%$ \\
\hline 8 & $78 \%$ \\
\hline 9 & $97 \%$ \\
\hline 10 & $94 \%$ \\
\hline 11 & $94 \%$ \\
\hline
\end{tabular}

Task Success is calculated with binary success. If the success rate percentage is bigger than $78 \%$, the task can be completed properly. Table XI shows the success rate of each task given to the respondents.

Table XI shows the success rate of each task. When doing the task 7 , some respondents did some mistakes by choosing the wrong data to be filtered. Respondents also print and display the wrong planting calendar. Another variable to be analyzed is farmer respondent's efficiency. Average click to finish all tasks is 59 while the predetermined value for farmer respondents to finish the task is 51. It means that there is difference on both two values. It is found during the test that some respondents faced difficulties to find some buttons on its page.

\section{3) General user respondents}

Similarly with Farmer respondents and system administrators, researchers carried out analysis for benchmark maximum time limit. It is determined by calculating average time of 5 sample respondents for each task.

Table XII shows the maximum time for general user respondents. There are 6 respondents for general user. After finishing the test, the data is analyzed to get the number of successful respondents and unsuccessful respondents. Table XIII below shows the number of successful and unsuccessful respondents for each task. 
TABLE XII. BenChMARK MAXIMUM TIME FOR GeNERAL USERS

\begin{tabular}{|c|c|c|c|c|c|c|c|}
\hline Task & User 1 & User 2 & User 3 & User 4 & User 5 & Avg & Max Time (Avg * 2) \\
\hline 1 & 12.4 & 13 & 8.6 & 10.3 & 15.2 & 11.9 & 23.8 \\
\hline 2 & 8.7 & 10.1 & 10.3 & 12.7 & 14.8 & 11.32 & 22.64 \\
\hline 3 & 2.3 & 6.6 & 19.3 & 13 & 23.9 & 13.02 & 26.04 \\
\hline 4 & 11.9 & 6.6 & 8.8 & 7.9 & 13.6 & 9.76 & 19.52 \\
\hline 5 & 6.8 & 7.6 & 11.9 & 6.9 & 12.3 & 9.1 & 18.2 \\
\hline 6 & 17.7 & 17.4 & 4 & 16.6 & 23.7 & 15.88 & 31.76 \\
\hline 7 & 6.8 & 5.8 & 18.4 & 8.9 & 12.5 & 10.48 & 20.96 \\
\hline 8 & 18.9 & 14.7 & 11.9 & 12.2 & 16.4 & 14.82 & 29.64 \\
\hline 9 & 3.7 & 5.2 & 4 & 4.2 & 6 & 4.62 & 9.24 \\
\hline 10 & 20.1 & 25.8 & 18.4 & 23.9 & 29.6 & 23.56 & 47.12 \\
\hline 11 & 17.1 & 37.1 & 10.8 & 40.3 & 45.9 & 30.24 & 60.48 \\
\hline 12 & 25.2 & 23.1 & 17.3 & 30.8 & 69.4 & 33.16 & 66.32 \\
\hline 13 & 40.2 & 43.2 & 39.9 & 50.8 & 76.9 & 50.2 & 100.4 \\
\hline 14 & 26.9 & 15 & 13.6 & 17 & 39.8 & 22.46 & 44.84 \\
\hline 15 & 40.8 & 39.5 & 48 & 44.3 & 75.9 & 49.7 & 99.4 \\
\hline 16 & 27.8 & 21.1 & 15 & 24.4 & 32.7 & 24.2 & 48.4 \\
\hline
\end{tabular}

TABLE XIII. NUMBER OF RESPONDENTS DID TASK BELOW AND ABOVE AVERAGE TIME AND AVERAGE TIME TO FINISIH TASK

\begin{tabular}{|l|l|l|l|}
\hline Task & $\begin{array}{l}\text { Number of } \\
\text { Respondents } \\
\text { Below Average } \\
\text { Time }\end{array}$ & $\begin{array}{l}\text { Number of } \\
\text { Respondents } \\
\text { Above Average } \\
\text { Time }\end{array}$ & $\begin{array}{l}\text { Average } \\
\text { Time } \\
\text { Used }\end{array}$ \\
\hline 1 & 3 & 3 & 12.5 \\
\hline 2 & 5 & 1 & 16.18 \\
\hline 3 & 6 & 0 & 9.016 \\
\hline 4 & 2 & 4 & 16.1 \\
\hline 5 & 1 & 5 & 22.4 \\
\hline 6 & 2 & 4 & 15.75 \\
\hline 7 & 6 & 0 & 9.25 \\
\hline 8 & 4 & 2 & 18.24 \\
\hline 9 & 6 & 0 & 5.53 \\
\hline 10 & 2 & 4 & 32.15 \\
\hline 11 & 3 & 3 & 38.7 \\
\hline 12 & 6 & 0 & 27.85 \\
\hline 13 & 5 & 1 & 51.38 \\
\hline 14 & 4 & 2 & 23.85 \\
\hline 15 & 5 & 1 & 53.16 \\
\hline 16 & 3 & 3 & 19.73 \\
\hline
\end{tabular}

Table XIII shows the number of successful and unsuccessful respondents finishing the task before maximum time. There are some tasks with the number of unsuccessful respondents are so high (more than 3 respondents). While doing the test task 1, 4, and 5, respondents were not able to find the display button and made respondents are not able to finish the tasks on time. Respondents found similar problem with display or detail button on task 6. Another case found on this test is respondents found difficulty to use search bar. Respondents are also hard to find "Summary" button since this button is located on the bottom of page. Respondents should scroll down the page. There were some mistakes that the respondents did: (1) respondents are not able to visit summary page; (2) respondents are failed to filter based on specific keywords; (3) respondents are wrong to choose the appropriate menu.
TABLE XIV. SUCCESSFUL RATE OF EACH TASK

\begin{tabular}{|l|l|}
\hline Task & Success Rate \\
\hline 1 & $100 \%$ \\
\hline 2 & $100 \%$ \\
\hline 3 & $100 \%$ \\
\hline 4 & $100 \%$ \\
\hline 5 & $100 \%$ \\
\hline 6 & $100 \%$ \\
\hline 7 & $100 \%$ \\
\hline 8 & $100 \%$ \\
\hline 9 & $100 \%$ \\
\hline 10 & $66.67 \%$ \\
\hline 11 & $50 \%$ \\
\hline 12 & $100 \%$ \\
\hline 13 & $83.33 \%$ \\
\hline 14 & $66.67 \%$ \\
\hline 15 & $83.33 \%$ \\
\hline 16 & $66.67 \%$ \\
\hline
\end{tabular}

TABLE XV. SUCCESSFUL RATE OF EACH TASK

\begin{tabular}{|l|l|l|l|l|}
\hline \multirow{2}{*}{ Respondents } & \multicolumn{4}{|l|}{ Average } \\
\cline { 2 - 5 } & Time Per Task & $\begin{array}{l}\text { Task } \\
\text { Success }\end{array}$ & Clicks & Efficiency \\
\hline System Administrator & $52 \%$ & $79 \%$ & $95 \%$ & $50 \%$ \\
\hline General Users & $66 \%$ & $84 \%$ & $70 \%$ & $83 \%$ \\
\hline Farmers & $66 \%$ & $91 \%$ & $69 \%$ & $91 \%$ \\
\hline
\end{tabular}


Table XIV shows success rate of each task. Task 1-9, there is no respondent made errors during finishing the task. Otherwise, there is $33.33 \%$ respondents who did some errors finishing the task 10,14, and 16 . There is $16.67 \%$ respondents who are not succeed to finish the task 13 and 15 . While $50 \%$ respondents are failed finishing the task 11.

Minimum number of click to finish tasks is 69 and the average of respondents click finishing the task is 101. This minimum number of click cannot be achieved since respondents are difficult to find the summary button. The location of the button is not able to be seen clearly.

\section{Combining Metrics based on Percentage}

Table XV shows the metric based on percentage. This technique is to combine different scale of value, convert it into percentage, and calculate the average of each parameters (time per task, task success, number of clicks, and efficiency). Based on table $\mathrm{XV}$, average time to do task for system administrator is $52 \%$ from maximum time. The usage of option button cannot be understood easily for the respondents. System Administrator respondents only $79 \%$ are succeed to finish tasks because some respondents did the activities on the wrong page. The number of clicks is $95 \%$. It means that users click the correct button. On the contrary, the accuracy is only $50 \%$ due to system administrator respondents are not able to finish some tasks.

General user respondents conducted and finished the task well. The average time to do task is $66 \%$ from the maximum time with the success rate around $84 \%$. There are some failed activities which users are not able to finish it because of difficulties to translate English button, for example submit button. While the number of click is $70 \%$ and the efficiency is $83 \%$. The average number of efficiency for general users is higher than system administrator.

Farmer respondents finished tasks with the average time $66 \%$. Some respondents are failed to finish the task because of the usage of the wrong symbol. Thus, the respondents are not able to understand the meaning. User interface of the system does not provide good information to the respondents. On the contrary, the number of succeed respondents to finish the tasks is $91 \%$ with efficiency around $91 \%$. It means that most of the farmer respondents are able to finish the task but some of them need additional time to finish the task.

\section{Improvement Recommendation}

Improvement recommendation is given according to the task test result, feedback from the respondents, and the analysis of the data from the task test result. Table XVI shows the improvement recommendation for the systems.

Table XVI shows the improvement recommendation for each user. Recommendations are categorized into 3 users. Some recommendations are the same, for instance in each user, there is a recommendation to display current active username on page, additional icon is required for each button, different colour between header and footer.
TABLE XVI. IMPROVEMENT RECOMMENDATION

\begin{tabular}{|c|c|}
\hline $\begin{array}{l}\text { Responden } \\
\text { ts }\end{array}$ & Recommendations \\
\hline $\begin{array}{l}\text { System } \\
\text { Administrat } \\
\text { or }\end{array}$ & $\begin{array}{l}\text { 1. Menu and navigation should use different colour } \\
\text { 2. Active menu should be highlighted } \\
\text { 3. System should display that the system is an agriculture } \\
\text { system } \\
\text { 4. Information about how to care of plant should be } \\
\text { available } \\
\text { 5. Additional picture for each plant is required } \\
\text { 6. There should be changes in menu naming } \\
\text { 7. User interface makes some distractions } \\
\text { 8. Searching is not addressing what is being sought } \\
\text { 9. Icon is required on each button } \\
\text { 10. Navigation should be changed to accordion type that will } \\
\text { made easy to be scrolled. } \\
\text { 11. Header and footer should use different colour } \\
\text { 12. Active username should be visible }\end{array}$ \\
\hline $\begin{array}{l}\text { General } \\
\text { Respondent } \\
\mathrm{s}\end{array}$ & $\begin{array}{l}\text { 1. Icon }(+) \text { can be replaced with icon }(\nabla) \\
\text { 2. Active menu should be highlighted } \\
\text { 3. Accordion menu type should be used in order to ease user } \\
\text { to scroll } \\
\text { 4. Active username should be visible } \\
\text { 5. Sort function will be added with icon and background } \\
\text { 6. Header and footer should use different colour }\end{array}$ \\
\hline Farmers & $\begin{array}{l}\text { 1. Icon is required on each button } \\
\text { 2. Indonesian language should be used in each button } \\
\text { 3. Button edit, delete, and summary should be visible to the } \\
\text { user } \\
\text { 4. Accordion menu type should be used in order to ase user } \\
\text { to scroll } \\
\text { 5. Active username should be visible } \\
\text { 6. Summary button will be placed closer to the content in } \\
\text { order to ease user finding the button } \\
\text { 7. Distance between column in each table will be narrowed } \\
\text { down. User does not need to click additional button }\end{array}$ \\
\hline
\end{tabular}

\section{E. Improvement Result}

Improvement recommendation has been generated. Based on those recommendations, researchers try to fulfill the improvement needs. The improvements are arranged based on the recommendations for all 3 category user.

\section{1) Highlighting the active menu}

Figure 6 shows the changes before and after the revision. On the left, it is shown that active menu was not highlighted. On the right, it is shown that active menu has been highlighted.
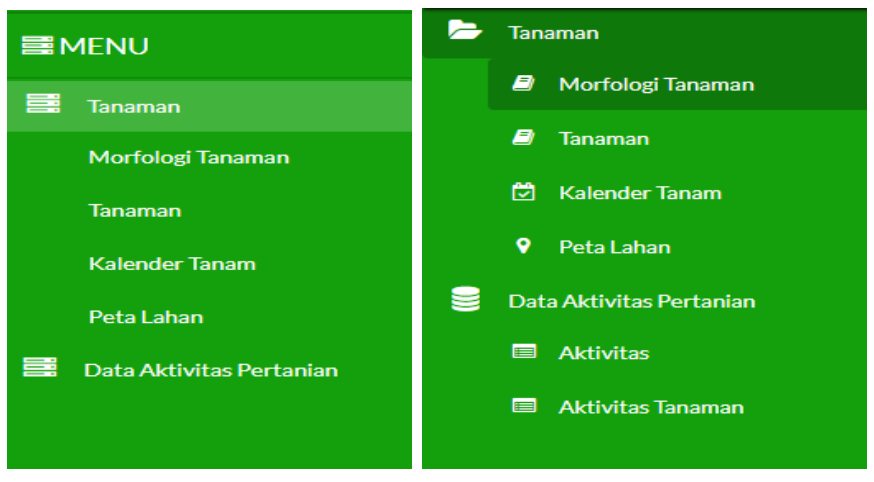

Fig. 6. Menu before the Revision (Left) and after the Revision (Right). 
2) Changes in Icon (+) to Icon $(\boldsymbol{\nabla})$

Figure 7 shows the icon (+) before the changes. That icon has been replaced with icon $(\boldsymbol{\nabla})$ which is displayed in figure 8 .
The changes also include removal of show button. Show button has been removed (figure 8). User is only able to delete and edit the record.

\begin{tabular}{|c|c|c|c|c|c|}
\hline No & $\begin{array}{l}\text { Nama } \\
\text { Tanaman }\end{array}$ & Nama Kalender & $\begin{array}{l}\text { Masa Tanam } \\
\text { (hari) }\end{array}$ & Kabupaten & Provinsi \\
\hline$(\oplus 1$ & Padi & Kalender Tanam Padi Bantul DIY 2016 & 90 & Bantul & $\begin{array}{l}\text { Daerah Istimewa } \\
\text { Yogyakarta }\end{array}$ \\
\hline$\odot 2$ & Padi & $\begin{array}{l}\text { Kalender Tanam Padi Kulon Progo DIY } \\
2016\end{array}$ & 90 & Kulon Progo & $\begin{array}{l}\text { Daerah Istimewa } \\
\text { Yogyakarta }\end{array}$ \\
\hline Pili & Lihat & Hapus & & & \\
\hline$(+3$ & Padi & $\begin{array}{l}\text { Kalender Tanam Padi Gunungkidul DIY } \\
2016\end{array}$ & 99 & Gunungkidul & $\begin{array}{l}\text { Daerah Istimewa } \\
\text { Yogyakarta }\end{array}$ \\
\hline
\end{tabular}

Fig. 7. Icon (+) before Recommendation Changes.

\begin{tabular}{|c|c|c|c|c|c|}
\hline No & Nama Morfologi & Nama Divisi & Nama Sub Divisi & Ordo & Famili \\
\hline$\Delta 1$ & jagung & jagung & jagung & jagung & fabaceace \\
\hline Pilih & Hapus & & & & \\
\hline$\nabla 3$ & Morfologi Bawang Merah & Magnolioph & Liliopsida & Asparagale & Amaryllida \\
\hline$\nabla 4$ & Morfologi Bawang Putih & Magnolioph & Liliopsida & Asparagale & Alliaceae \\
\hline$\nabla 5$ & Morfologi Bayam & Magnolioph & Magnoliops & Caryophyll & Amaranthac \\
\hline
\end{tabular}

Fig. 8. Improvement Result of Icon and Display Button.

3) Moving the searching text box to make it visible to user

Some respondents had problem while they should search specific data. They found difficulties to search and the menu is required to be moved.

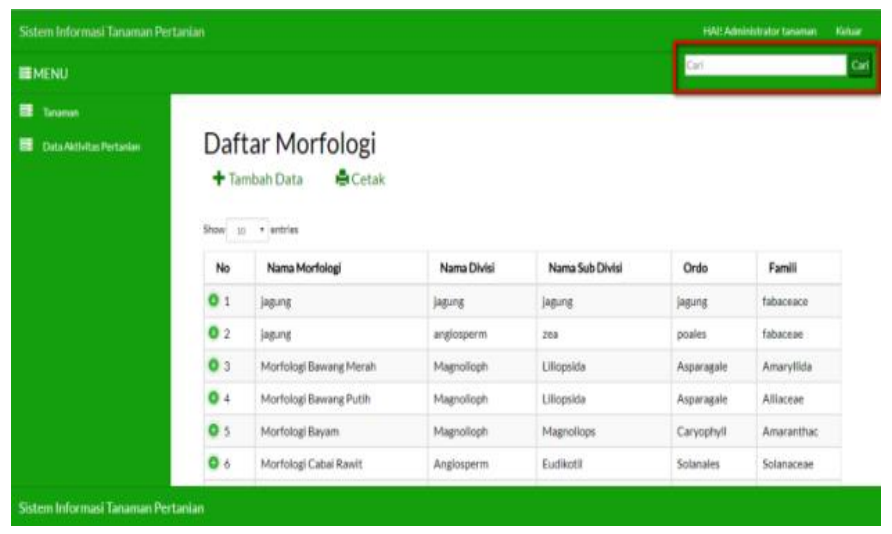

Fig. 9. Search Menu Location before Improvement Changes.
Figure 9 and 10 shows the location of the searching menu. Searching menu before the improvement changes is located on the left top on each page. After the improvement changes, searching menu is located little bit down. This movement is based on the test recommendation. While doing the task test, respondents needed extra time to find the searching menu.

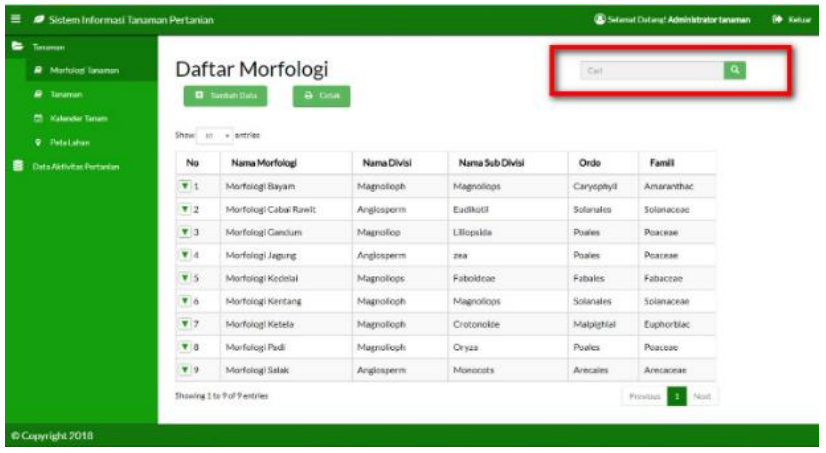

Fig. 10. Search Menu Location after Improvement Changes. 
4) Changes on add, print, sorting menu, and searching тепи

Farmer respondents found difficulties while adding, printing, sorting, and searching data. Therefore, additional icon is needed to ease user. Figure 11 shows the menu before changes and figure 12 shows the menu after changes.

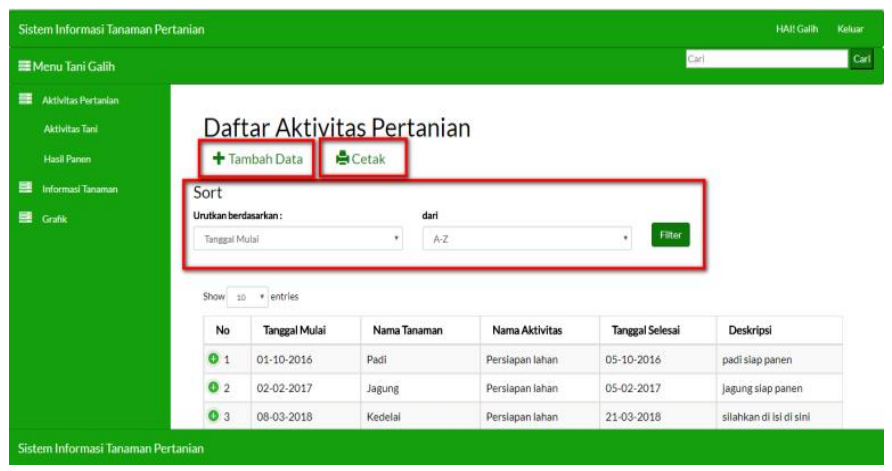

Fig. 11. Add, Print Button, Sorting Menu, and Searching Menu before Changes.

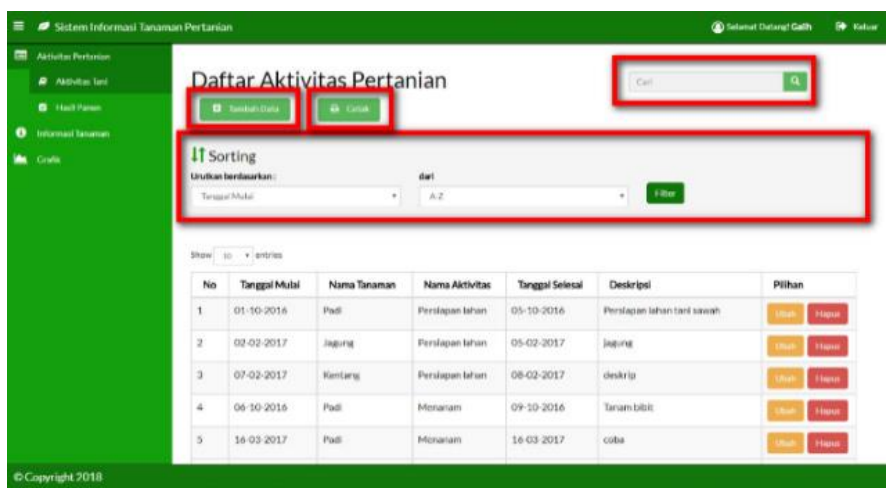

Fig. 12. Add, Print Button, Sorting Menu, and Searching Menu after Changes.

Figure 11 shows the add button, print, sorting menu, and searching menu before changes. Button should be changes to ease the user while searching menu should be moved down slightly. Figure 12 shows the improvement changes for those buttons and menus.

\section{CONCLUSIONS}

Based on the research, there are some conclusions as follows:

1) Usability problems for agriculture activity information system are the usage of inappropriate button icon, button position does not locate on the right position, and navigation of menu sidebar does not display current active menu. User also faced difficulties problem with symbol button.

2) Task test from usability analysis for agriculture activity information system: three kinds of respondent (system administrator, farmer, and general user) assess that agriculture activity information system is good with average overall assessment value $69 \%-79 \%$.

3) There are some improvement recommendations that will improve system usability. Those recommendations has been followed up by doing several refinements.

\section{REFERENCES}

[1] The World Bank, "Priority Issues for Indonesian Agriculture," The World Bank, 2005.

[2] The Organisation for Economic Co-operation and Development, "OECD Economic Surveys Indonesia," The Organisation for Economic Cooperation and Development, 2015.

[3] Deloitte, "e-Transform Africa: Agriculture Sector Study - Sector Assessment and Opportunities for ICT," Delloite Project Report, 2012.

[4] R. Delima, F. Galih and A. Wibowo, "Development of Crop and Farmer Activity Information System," Researchers World, vol. VIII, no. 4, pp. 180 - 189, October 2017

[5] T. K. Chiew and S. S. Salim, "Webuse: Website Usability Evaluation Tool," Malaysian Journal of Computer Science, vol. 16, no. 1, pp. 4757, 2003.

[6] N. Bevan, "Measuring Usability as Quality of Use," Software Quality Journal, vol. 4, pp. 115-150, 1995.

[7] J. Mvungi and T. Tossy, "Usability Evaluation Method and Principle for the Web," International Journal of Computer Science and Software Engineering, vol. 4, no. 7, pp. 165-171, 2015.

[8] R. L. Mack and J. Nielsen, Usability Inspection Methods, New York: John Wiley \& Sons, 1994

[9] N. F. M., EL-firjani, E. K. Elberkawi and A. M. Maatuk, "A Method for Website Usability Evaluation: A Comparative Analysis," International Journal of Web \& Semantic Technology, vol. 8, no. 3, pp. 1-11, 2017.

[10] J. Nielsen, "Usability 101 - Introduction to Usability," 4 January 2012. [Online]. Available: https://www.nngroup.com/articles/usability-101introduction-to-usability/. [Accessed 16 September 2018].

[11] W. E. Y. Retnani, Y. P. Prayogi, B. Prasetyo and A. N. M. M. A. R, "Usability Testing to Evaluate the Library's Academic," in International Conference on Computer Applications and Information Processing Technology, Bali, 2017.

[12] S. Lestari, "Analisis Usability Web (Studi Kasus Website UMKM Binaan BPPKU KADIN Kota Bandung)," Jurnal Ilmiah Teknologi Informasi Terapan, vol. 1, no. 1, pp. 46-51, 2014.

[13] M. Ashraf, F. S. Cheema, T. Saba and A. Mateen, "Usability of Government Websites," International Journal of Advanced Computer Science and Applications, vol. 8, no. 8, pp. 163 - 167, 2017.

[14] N. K. Kiget, G. Wanyembi and A. I. Peters, "Evaluating Usability of eLearning Systems in Universities," International Journal of Advanced Computer Science and Application, vol. 5, no. 8, pp. 97-102, 2014.

[15] D. P. Sari, N. Susanto and Z. L. Z. Polii, "Analysis of the Community Website Usability Using Koohang's Model Based on Task Performance Comparasion Result," in International Conference of Industrial, Mechanical, Electrical, Chemical Engineering, Surakarta, 2016. 